\title{
Treatment of a simulated phenolic effluent by heterogeneous catalytic ozonation using $\mathrm{Pt} / \mathrm{Al}_{2} \mathrm{O}_{3}$
}

\author{
Ana S. Fajardo, Rui C. Martins \& Rosa M. Quinta-Ferreira
}

To cite this article: Ana S. Fajardo, Rui C. Martins \& Rosa M. Quinta-Ferreira (2013) Treatment of a simulated phenolic effluent by heterogeneous catalytic ozonation using $\mathrm{Pt} / \mathrm{Al}_{2} \mathrm{O}_{3}$, Environmental Technology, 34:3, 301-311, DOI: 10.1080/09593330.2012.692720

To link to this article: https://doi.org/10.1080/09593330.2012.692720

Accepted author version posted online: 11 May 2012.

Published online: 21 Jun 2012.

Submit your article to this journal $\pi$

山 Article views: 157

Citing articles: 4 View citing articles $\sqsubset$ 


\title{
Treatment of a simulated phenolic effluent by heterogeneous catalytic ozonation using $\mathrm{Pt} / \mathrm{Al}_{2} \mathrm{O}_{3}$
}

\author{
Ana S. Fajardo, Rui C. Martins* and Rosa M. Quinta-Ferreira \\ CIEPQPF - Centro de Investigação em Engenharia dos Processos Químicos e Produtos da Floresta, GERSE - Group on Environment, \\ Reaction and Separation Engineering, Department of Chemical Engineering, Faculty of Sciences and Technology, University of \\ Coimbra, Coimbra, Portugal
}

(Received 13 February 2012; final version received 7 May 2012)

\begin{abstract}
Non-catalytic and catalytic ozonation over $\mathrm{Pt} / \mathrm{Al}_{2} \mathrm{O}_{3}$ were considered in the treatment of a synthetic effluent composed of six phenolic acids usually present in olive mill wastewaters. In both processes the medium $\mathrm{pH}$ affected the rate of ozone decomposition and the formation of hydroxyl radicals. The optimum values were achieved for the catalytic system under $\mathrm{pH}$ 7 with 93.0 and $47.7 \%$, respectively, of total phenol content and chemical oxygen demand (COD) removal, after 120 minutes of reaction. For $\mathrm{pH} 3$, the catalytic ozonation followed a free radical pathway perceived by the presence of radical scavengers. No significant structural differences were observed between the fresh and used solid catalyst in X-ray diffraction analysis. Aluminium leaching behaviour was also evaluated at the end of each experiment. Moreover, a sequence of feed-batch trials involving the catalyst reutilization exhibited almost constant activity during the operation time. Eco-toxicological tests were performed for both processes, revealing that the treated effluent still presents some ecological impact, although it is lower than that for the raw wastewater.
\end{abstract}

Keywords: catalytic ozonation; $\mathrm{Pt} / \mathrm{Al}_{2} \mathrm{O}_{3}$; catalyst characterization; phenolic acids; wastewater treatment

\section{Introduction}

Man has always interacted with the surrounding environment, modifying it according to his needs. In this evolutionary process, domestic, industrial and agricultural activities acquire an essential meaning to the welfare of modern society, leading to an exponential consumption of raw materials that contribute to the dramatic increase of the amount of pollutants discharged into the natural waters. Indeed, one of the major problems that humanity is facing today is related with water quantity and quality. Within this context, new techniques have been developed to remediate effluents and purify wastewaters to achieve the final legal desired characteristics [1-3].

The presence of phenolic mixtures in wastewater composition is a common factor shared by a number of industrial effluents. Phenolic compounds are organic substances usually present in agro-industrial effluents incorporating a significant contaminant load due to their high toxicity, refractory character and high stability in water [4-8].

In recent times, advanced oxidation processes (AOP) appeared as promising alternatives to conventional treatment techniques due to their efficiency in oxidizing a wide variety of organic contaminants by the generation of highly oxidative hydroxyl radicals [9-12]. Among them, catalytic ozonation has revealed high capacity for the degradation and mineralization of phenolic contaminants, lowering the negative effects on water quality [13-16]. In general, heterogeneous oxidation has shown to be promisingly efficient for the removal of organic compounds $[17,18]$; it is necessary, however, to pay attention to the activity and stability of the catalysts whose characteristics depend on the operating conditions. Leaching of the catalytic species, poisoning of the active sites or fouling of the solid surface by intermediate reaction products are factors that determine the durability of the selected catalysts [14]. Those utilized in ozonation comprise mostly transient metals, with and without ceramic supports, while, in recent literature, some noble metals such as $\mathrm{Ru}, \mathrm{Pt}, \mathrm{Rh}$, Ir and Pd have also been applied in the gaseous and aqueous phase [19-21]. $\mathrm{Pt} / \mathrm{Al}_{2} \mathrm{O}_{3}$ was the most effective for formic acid removal, according to Lin et al. [22], and $\mathrm{Pt} / \gamma-\mathrm{Al}_{2} \mathrm{O}_{3}$ clearly enhanced the mineralization of phenol and intermediates and, to a lesser extent, the dimethyl phthalate under the experimental conditions used by Chang et al. [21,23]. The mechanism of these catalysts was explained by Legube and Karpel Vel Leitner [24]. Pines and Rechow [25] evaluated the ozonation activity of $\mathrm{Ru} / \mathrm{Al}_{2} \mathrm{O}_{3}, \mathrm{Pt} / \mathrm{Al}_{2} \mathrm{O}_{3}$ and $\mathrm{Pt} /$ activated carbon through the decomposition of $p$-chlorobenzoic acid, a non-adsorbing pollutant that does not react directly with molecular ozone. It was pointed out that $\mathrm{Ru} / \mathrm{Al}_{2} \mathrm{O}_{3}$ improved the removal of

\footnotetext{
${ }^{*}$ Corresponding author. Email: martins@eq.uc.pt
} 
$p$-chlorobenzoic. For dimethyl phthalate ozonation, Zhou et al. [26] verified that $\mathrm{Ru} / \mathrm{Al}_{2} \mathrm{O}_{3}$ doped with $\mathrm{Ce}$ remarkably enhanced its activity, besides reducing the leaching phenomenon.

Indeed, noble metals seem to be a new direction to take into account in environmental catalysts because, in spite of their higher initial costs, they are resistant to corrosion and oxidation, unlike transient metals. Therefore, this paper aims to analyse the catalytic ozonation over $\mathrm{Pt} / \mathrm{Al}_{2} \mathrm{O}_{3}$ of a mixture of six phenolic acids usually present in real olive mill wastewater (OMW), also targeting its activity and stability. This process is compared with the case where ozone is used alone, being given special emphasis to the effluent's ecological impact.

\section{Materials and methods}

\subsection{Wastewater preparation}

Six phenolic acids, typically found in OMWs, namely 3,4,5trihydroxybenzoic (98\%), 3,4-dihydroxybenzoic (97\%), trans-cinnamic (99\%), 3,4,5-trimethoxybenzoic (99\%), 3,4-dimethoxybenzoic (99\%) and 4-hydroxybenzoic (99\%) acids were used to prepare the synthetic effluent, with a concentration of $100 \mathrm{mg} / 1$ of each compound [27]. The first two acids were obtained from Fluka and Acros Organics, respectively, and all the others from Sigma-Aldrich. The acids were used as received without further purification.

\subsection{Catalyst characterization and oxidation procedure}

Catalytic ozonation was carried out over a $\mathrm{Pt} / \mathrm{Al}_{2} \mathrm{O}_{3}$ catalyst ( $1 \%$ in $\mathrm{Pt}$ ), supplied by industry and characterized before and after its utilization. The morphology and textural properties were analysed at different scales/magnifications by scanning electron microscopy (SEM) with a JEOL JSM5310 and by X-ray diffraction (XRD) analysis using Philips PW 3040/00 X'Pert analyser. The Brunauer-EmmettTeller (BET) surface area $\left(S_{B E T}\right)$ was determined using nitrogen $\left(-196^{\circ} \mathrm{C}\right)$ with an accelerated surface area (ASAP 2000, Micromeritics). Porosity and pore size distribution were determined by mercury porosimetry (Poresizer 9320 , Micromeritics). Particle size distribution was assessed using a Malvern Mastersizer 2000 system. The catalyst stability in terms of Al leaching was evaluated by measuring its concentration in the liquid phase by atomic absorption (Perkin-Elmer 3300, Waltham, MA). The determination of the $\mathrm{pH}$ of zero point charge $\left(p \mathrm{H}_{z p c}\right)$ of $\mathrm{Pt} / \mathrm{Al}_{2} \mathrm{O}_{3}$ was performed according to the procedure proposed by Rivera-Ultrilla et al. [28].

Non-catalytic and catalytic ozonation were conducted at atmospheric pressure and room temperature. The reactor consisted of a glass vessel ( $500 \mathrm{ml}$ capacity) operating in a semi-batch mode with magnetic stirring (500-700 rpm). In every experiment, the reactor was charged with $500 \mathrm{ml}$ of the model solution at the beginning of the test and the gas was continuously bubbled with an ozone concentration of $20 \mathrm{gO}_{3} / \mathrm{Nm}^{3}$ measured by a BMT 963 vent ozone analyser (BMT Messtechnik, Berlin, Germany). Ozone was produced from a pure oxygen stream $(99.999 \%$ Praxair, Portugal) in a BMT $802 \mathrm{~N}$ ozone generator (BMT Messtechnik, Berlin, Germany) with a flow rate of $0.51 / \mathrm{min}$. The $\mathrm{pH}$ was continuously measured using a Crison micropH

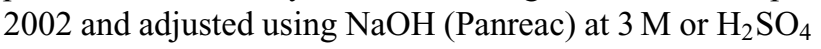
(Panreac) at $2 \mathrm{M}$ whenever necessary. The catalytic ozonation experiments were carried out in slurry conditions with $10 \mathrm{~g} / \mathrm{l}$ of powder catalyst introduced into the reactor just before starting to feed the ozone. The diameter range of the catalyst particles was $125-250 \mu \mathrm{m}$ to ensure a chemical regime [29]. In addition, to evaluate the inhibition effect of radical scavengers, sodium carbonate at $0.01 \mathrm{M}$ (Riedelde Häen) or tert-butanol (Fluka) at $0.005 \mathrm{M}$ were used. Samples were withdrawn at specific time intervals, and the solution was immediately separated from the catalyst by filtration through $0.45 \mu \mathrm{m}$ disposable filters (Double Rings) for further analysis. The same procedure was adopted when the adsorption capacity of the catalyst was evaluated, but without the introduction of ozone into the system.

\subsection{Analytical techniques}

Total phenol content (TPh) was measured in terms of gallic acid (GA) by the Folin-Ciocalteau method. The procedure is described elsewhere by Martins et al. [30]. The absorbance was determined with a T60 PG Instruments spectrophotometer, at $765 \mathrm{~nm}$. Chemical oxygen demand (COD) and biochemical oxygen demand $\left(\mathrm{BOD}_{5}\right)$ were determined by the method stipulated in Standard Methods [31]. A Knauer high-performance liquid chromatography (HPLC) system was used to measure the concentration of each compound of the synthetic effluent and samples were injected via an autosampler (Knauer, Smartline 3800) with an injection volume of $20 \mu \mathrm{l}$. The mobile phase $(20 \%$ of methanol in water slightly acidified with phosphoric acid) was pumped using a Knauer WellChrom K-1001 pump at a flow rate of $1 \mathrm{ml} / \mathrm{min}$ through a $\mathrm{C} 18$ column at $85^{\circ} \mathrm{C}$, and detection was performed at $280 \mathrm{~nm}$ in an ultraviolet (UV) detector (Knauer). The bioluminescence test was performed using a LUMIStox (Dr. Lange, Germany) according to the standard method DIN/EN/ISO 11348-2, which is based on light inhibition of the luminescent marine bacteria Vibrio Fischeri. The eco-toxicity levels were expressed as $E C$ values, which represent the concentration of a sample that restrains $20 \%\left(E C_{20}\right)$ and $50 \%\left(E C_{50}\right)$ of bacteria light emission. The test kits were used without modification. All samples were prepared in aqueous solutions with $2 \%$ of $\mathrm{NaCl}$ and $\mathrm{pH} 7$. Prior to the use of bacteria, they were reactivated with the solution provided and maintained at $15^{\circ} \mathrm{C}$ in LUMIStherm (Dr. Lange, Germany). The light produced was measured before and after the bacteria was incubated for 15 minutes at $15^{\circ} \mathrm{C}$ with different dilutions of the pollutants. The $E C_{20}$ and $E C_{50}$ values were treated and directly supplied by the LUMIStox equipment. 
Samples were measured at least in duplicate and the deviations between runs were always lower than $8 \%$ for $\mathrm{TPh}$ and $\mathrm{COD}$, and $20 \%$ for $\mathrm{BOD}_{5}$ determinations. For the Acute Toxicity LUMIStox Bioassay the deviations do not differ more than $2 \%$. In fact, the results presented in the figures correspond to the average of those measurements, including the respective standard deviations. Some experiments were randomly run in duplicate to ensure the reproducibility of the results.

\section{Results and discussion}

\subsection{Characterization of the synthetic effluent}

The synthetic effluent was composed of six phenolic acids typically present in OMWs. Figure 1 shows the molecular formula of the compounds used in this study.

Wastewater characteristics play a significant role in its purification and, in our case, raw parameters were measured and are listed in Table 1.

According to the Portuguese environmental laws, an effluent should not have $\mathrm{COD}$ and $\mathrm{BOD}_{5}$ values higher than 150 and $40 \mathrm{mgO}_{2} / 1$, respectively, to be released into the environment (Portuguese Decree Law $\mathrm{N}^{\circ} 236 / 98$ of 1 August). The synthetic effluent shows a high organic charge featuring $1068 \mathrm{mgO}_{2} / 1$ in $\mathrm{COD}$, in addition to $352 \mathrm{mgGA} / 1$ in phenolic content. The $\mathrm{BOD}_{5}$ value $(372 \mathrm{mg}$ $\mathrm{O}_{2} / \mathrm{l}$ ) may not allow the direct application of a biological treatment. In fact, the ratio $\mathrm{BOD}_{5} / \mathrm{COD}$ is equal to 0.35 , while a wastewater is considered as totally biodegradable when this ratio is higher than 0.4 [32]. For other authors it is suitable to consider that for values higher than 0.3 , the wastewater may be partially biodegradable $[33,34]$. Nevertheless, the treatment of OMWs has always been considered a challenging issue for scientists, due to their high organic
Table 1. Synthetic effluent characterization.

\begin{tabular}{lc}
\hline Characteristics & Values \\
\hline $\mathrm{TPh}(\mathrm{mgGA} / 1)$ & $352 \pm 46$ \\
$\mathrm{COD}\left(\mathrm{mgO}_{2} / 1\right)$ & $1068 \pm 30$ \\
$\mathrm{BOD}_{5}\left(\mathrm{mgO}_{2} / 1\right)$ & $372 \pm 20$ \\
$\mathrm{BOD}_{5} / \mathrm{COD}$ & 0.35 \\
$E C_{20}(\%)$ & $10.0 \pm 2$ \\
$E C_{50}(\%)$ & $35.5 \pm 2$ \\
$\mathrm{pH}$ & 3.0 \\
\hline
\end{tabular}

loading (phenolic compounds) that is hard to biodegrade, seasonal production (occurs typically between December and March) and high territorial scattering with small localized mills, leading to a high variability, which is not very suitable for direct biological treatment [5-7], sustaining the necessity of a chemical oxidation process [35]. In order to assess the environmental impact of this phenolic wastewater over ecosystems, the toxicity of the initial mixture was evaluated and it was verified that a solution involving only 10.0 and $35.5 \%$ of the pollutant sample led to 20 and $50 \%$ of the Vibrio Fischeri's population light production inhibition respectively $\left(E C_{20}=10 \%\right.$ and $\left.E C_{50}=35.5 \%\right)$, which demonstrates its high negative impact over life forms.

\subsection{Non-catalytic ozonation}

The $\mathrm{pH}$ effect was studied at four different values: $3,5,7$ and 9. For experiments involving alkaline $\mathrm{pH}$ values, $\mathrm{NaOH}$ $(3 \mathrm{M})$ was used to maintain the desired level. This parameter affects the reaction process by its impact on the rate of the ozone decomposition and formation of hydroxyl radicals, which is known to be favoured at high $\mathrm{pH}$ values [36].<smiles>COc1cc(C(=O)O)cc(OC)c1OC</smiles><smiles>O=C(O)c1ccc(O)cc1</smiles><smiles>O=C(O)c1ccc(O)c(O)c1O</smiles><smiles>O=C(O)c1ccc(O)c(O)c1</smiles>

protocatechuic acid<smiles>O=C(O)/C=C/c1ccccc1</smiles>

trans-cinnamic acid<smiles>COc1ccc(C(=O)O)cc1OC</smiles>

veratric acid

Figure 1. The structure of the six phenolic acids that were added to the synthetic effluent. 

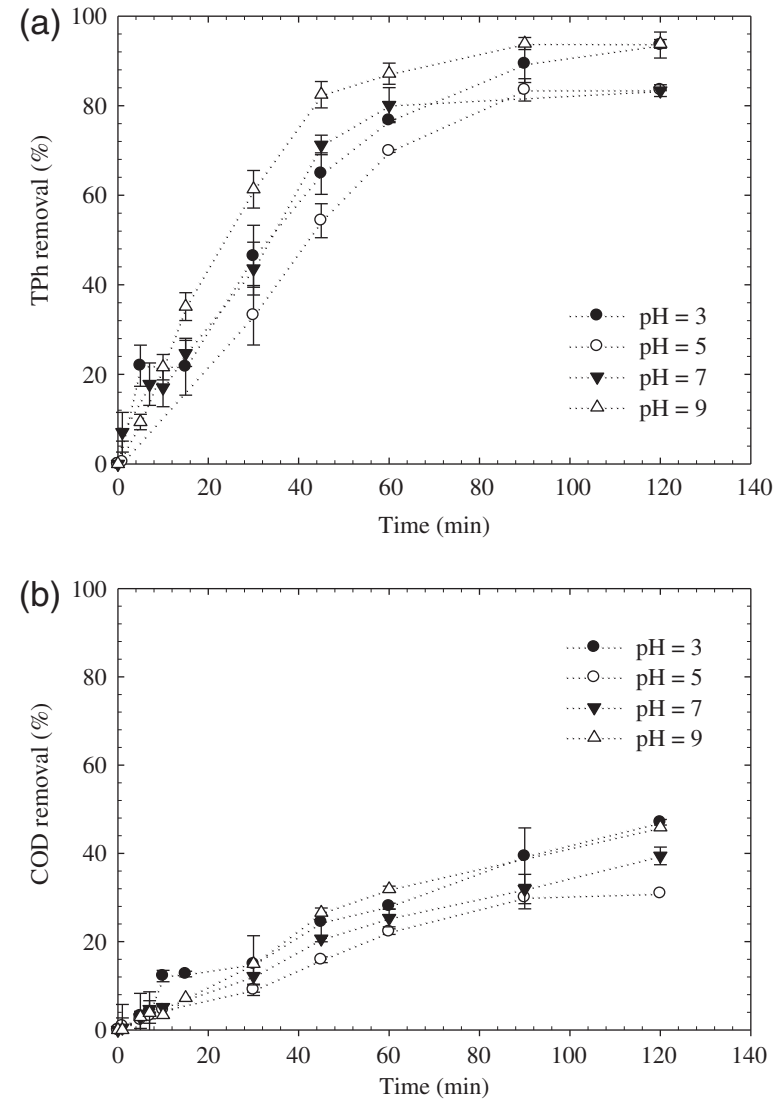

Figure 2. Effect of the medium $\mathrm{pH}$ on TPh (a) and COD (b) degradation by non-catalytic ozonation ( $0.02 \mathrm{gO}_{3} / 1$.min $)$.

Moreover, phenolic acids' reactivity may be higher in ionized forms, which are expected to be achieved for $\mathrm{pH}>$ $p K_{a}$. The $p K_{a}$ is a parameter that represents the strength of an acid, which is related with its capacity to ionize. Lower $p K_{a}$ values correspond to stronger acids. For phenolic acids, this value is around 4.5-5.5.

Figure 2(a) shows $\mathrm{TPh}$ removal trends at different $\mathrm{pH}$ values along the treatment time and, as can be observed, the degradation rate is high for all $\mathrm{pH}$ values used. In fact, ozone is very efficient in phenolic compounds' abatement, due to the strong electrophilic nature of its molecule that reacts directly with nucleophilic positions of the aromatic rings [19,24,37]. Moreover, the presence of electron donor groups, such as hydroxyl (HO), a strongly activating group, and methoxyl $\left(\mathrm{CH}_{3} \mathrm{O}\right)$, a moderate one, favours oxidation reactions of these compounds [29].

After 120 minutes, no significant differences were observed between results achieved at $\mathrm{pH} 3$ and $\mathrm{pH} 9$ (93.5 and $93.8 \% \mathrm{TPh}$ removal, respectively). Indeed, as pointed out, these two limit values are the most efficient in phenolic compound removal, benefiting from the increase of either ozone direct reactions ( $\mathrm{pH} 3$ ) or radical formation ( $\mathrm{pH} 9)$. At intermediate $\mathrm{pH} 5$ and 7, those two reaction routes are both competing, lowering the overall effectiveness (83.5 and $83.4 \% \mathrm{TPh}$ decrease). Ozonation chemistry is complex and it is characterized by driving oxidation in two possible mechanisms: direct reaction with the dissolved $\mathrm{O}_{3}$ and indirect reactions with the radical species $\mathrm{HO}^{\bullet}$ or $\mathrm{HO}_{2}^{\bullet}$, which are formed when ozone decomposes in water. Molecular ozone can directly react with dissolved pollutants, mainly by electrophilic attack, which is selective to major electronic density positions of the molecule. The radical mechanism is the path that joins ozonation in the AOP group, and can be promoted by hydroxyl ions (alkaline $\mathrm{pH}$ ) or other substances, such as transition metal cations (ferrous and ferric ions or by alumina), that promote ozone decomposition into high reactive and unselective hydroxyl radicals. The combination of both pathways for the removal of a compound will depend on its nature, the medium $\mathrm{pH}$ and the ozone dose. This explains the difference between the results obtained when ozonation is applied under various conditions to the same pollutant. As $\mathrm{pH}$ increases, so does the rate of decomposition of ozone in water. Usually under acidic conditions $(\mathrm{pH}<4)$, the direct pathway dominates, while for $\mathrm{pH} 9$ and above the mechanism changes to radicalar. Nevertheless, the phenolic acids degradation attained is very similar for both $\mathrm{pH}$ values due to the molecular ozone reactivity with the phenolic acid aromatic ring [14,15,38].

The COD abatement over time for the different $\mathrm{pH}$ values is shown in Figure 2(b), revealing the same pH effect but with lower degradation levels when compared with $\mathrm{TPh}$. For all $\mathrm{pH}$ values, COD removal exhibited a similar pattern up to 15 minutes with $10.0 \%$ decrease, diverging afterwards

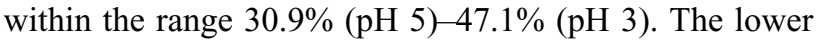
COD removal indicates that, despite the degradation of phenols, there is a subsequent formation of more refractory intermediate compounds that contribute to still-significant final COD values.

\subsection{Catalytic ozonation}

\subsubsection{Effect of $p H$}

Since $\mathrm{pH}$ is a key operating parameter for ozone solubility and stability in aqueous solution, besides influencing the catalyst surface properties, it is important to examine its impact in the catalytic ozonation of the phenolic solution. Figure 3(a) represents the wastewater phenolic content depletion along time, showing that total removal is also not achieved whichever $\mathrm{pH}$ value is used. Increasing the $\mathrm{pH}$ from 3 to 7 leads to an enhancement from 79.4 to $93.0 \%$ after 120 minutes, whereas at $\mathrm{pH} 9$ phenolic depletion decreases to $90.3 \%$. The highest activity of the catalyst was observed at $\mathrm{pH} 7$, close to its $p H_{z p c}$ value, which for $\mathrm{Pt} / \mathrm{Al}_{2} \mathrm{O}_{3}$ is 7.7. At higher $\mathrm{pH}$ medium values, the catalyst is negatively charged, as well as the phenolic acids (since their $p K_{a}$ is around 4.5-5.5), creating therefore repulsive electrostatic interactions between pollutants and the catalyst surface that may inhibit surface reactions. Figure 3(b) illustrates that the COD removal at the end of 120 minutes of reaction was slightly affected by $\mathrm{pH}$ values below $p H_{z p c}$, evolving as follows: $44.8 \%(\mathrm{pH} \mathrm{5}), 47.5 \%(\mathrm{pH} 3)$ and $47.7 \%(\mathrm{pH} 7)$, 

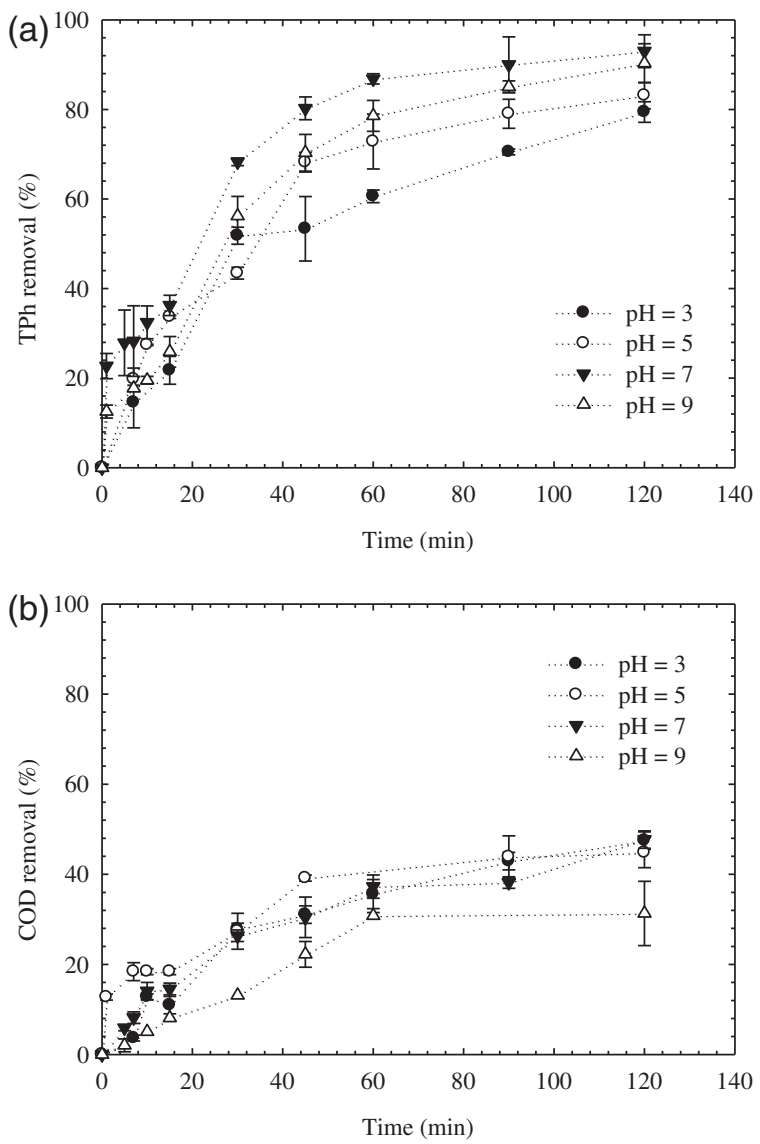

Figure 3. Effect of the medium $\mathrm{pH}$ on $\mathrm{TPh}$ (a) and COD (b) degradation by catalytic ozonation over $\mathrm{Pt} / \mathrm{Al}_{2} \mathrm{O}_{3}(10 \mathrm{~g} / 1$ of catalyst and $0.02 \mathrm{gO} 3 / 1 . \mathrm{min}$ ).

with the lowest result of $31.3 \%(\mathrm{pH} 9)$ achieved when the $\mathrm{pH}$ value is well below $p H_{z p c}$.

\subsubsection{Role of the catalyst over the catalytic ozonation pathway}

The efficiency of the catalytic ozonation process depends to a great extent on the catalyst and its surface characteristics, as well as the $\mathrm{pH}$ of the solution, which influences the properties of the active sites and ozone decomposition reactions in aqueous solutions. There are three possible mechanisms for the heterogeneous catalysed ozonation reaction [19,39]: adsorption of ozone on the catalyst surface leading to the formation of active species (such as hydroxyl radicals), which will react with the pollutants in liquid phase; adsorption of the organic pollutant; and reaction with free ozone or adsorption of both reactants with further surface reaction.

Some studies concluded that the generation of aqueous hydroxyl radicals due to ozone decomposition at the solid surface was the main mechanism responsible for the improvement of this process $[19,40]$. In order to verify the possible intervention of such radicals in the catalytic system under study, tests involving the presence of inorganic
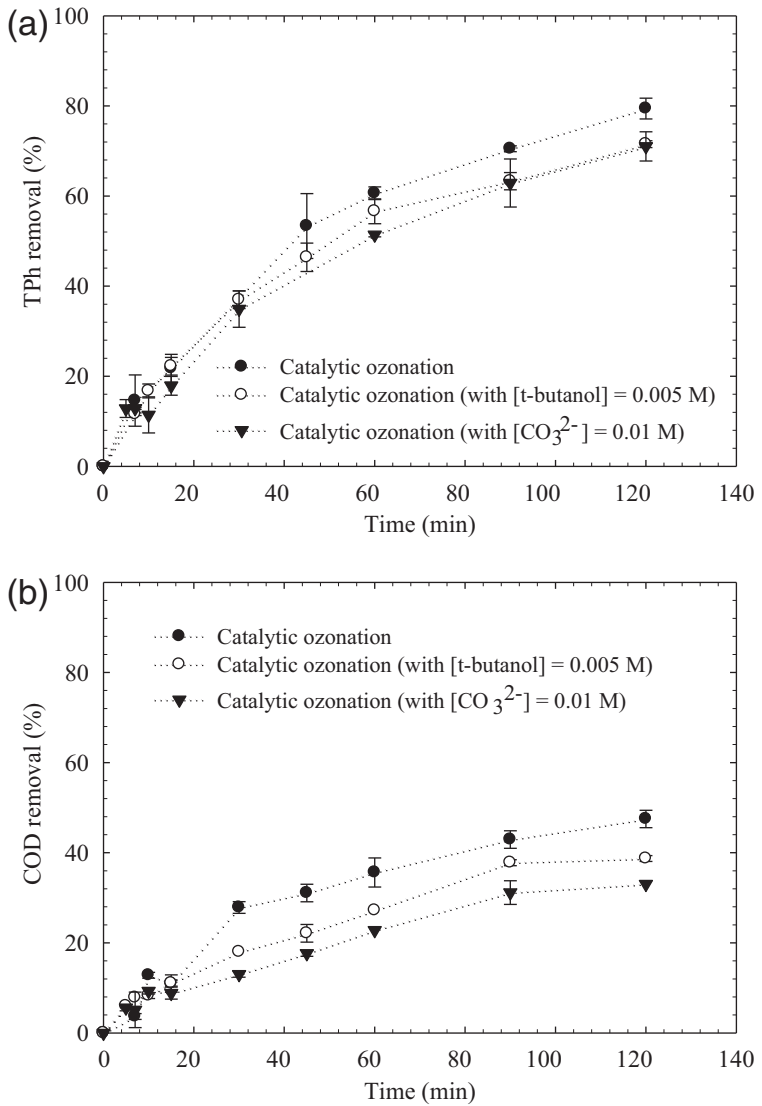

Figure 4. Effect of the presence of radical scavengers on the efficiency of catalytic ozonation over $\mathrm{Pt} / \mathrm{Al}_{2} \mathrm{O}_{3}$ regarding $\mathrm{TPh}$ (a) and COD (b) removal $\left(10 \mathrm{~g} / 1\right.$ of catalyst, $0.02 \mathrm{gO}_{3} / 1$ min and $\mathrm{pH}=3$ ).

(sodium carbonate) and organic (tert-butanol) radical scavengers were performed at $\mathrm{pH} 3$. This $\mathrm{pH}$ value was selected since it warrants that if hydroxyl radicals are produced in such circumstances this would be due to the interaction between $\mathrm{O}_{3}$ and the catalyst; this radicalar pathway is not generally recognized in non-catalytic ozonation for such low pH [19]. However, Figures 4(a) and (b) indicate that ozonation catalysed by $\mathrm{Pt} / \mathrm{Al}_{2} \mathrm{O}_{3}$ is negatively affected in the presence of organic and inorganic radical scavengers. $\mathrm{TPh}$ removal (Figure 4(a)) decreases from 79.4\% without radical scavengers to $71.5 \%$ with t-butanol and to $71.0 \%$ with carbonate. COD profiles (Figure 4(b)) follow a similar trend, although with lower values: $47.5,38.7$ and $33.0 \%$ of COD depletion, without radical scavengers, with the addition of t-butanol and carbonate, respectively. These results reveal that, in these conditions, the oxidation mechanism of the effluent over $\mathrm{Pt} / \mathrm{Al}_{2} \mathrm{O}_{3}$ occurs via a radical pathway, probably due to the decomposition of $\mathrm{O}_{3}$ over $\mathrm{Pt} / \mathrm{Al}_{2} \mathrm{O}_{3}$ surface. In this regard, an identical conclusion was taken from previous results of our research group involving the commercial N-150 catalyst when used in the decomposition of a similar phenolic wastewater [16]. Contrarily, the laboratory Mn-Ce-O 70/30 was shown to mainly pursue a mechanism 


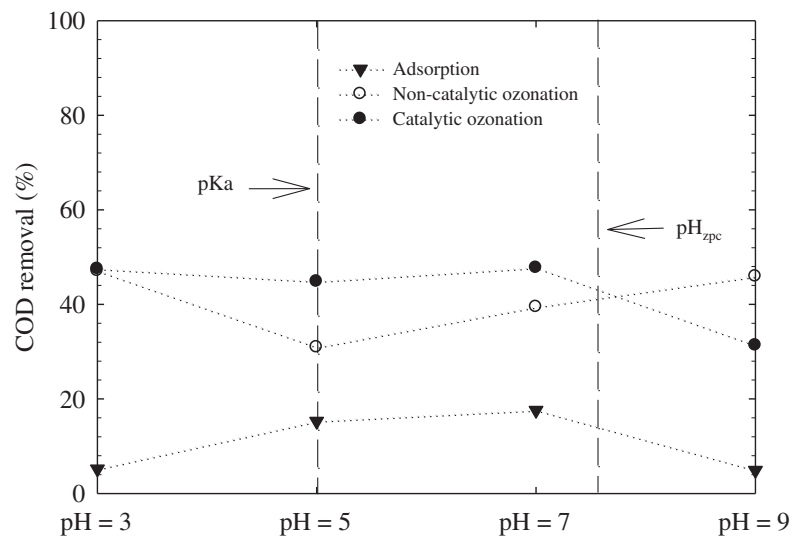

Figure 5. Evaluation of COD removal, during non-catalytic ozonation, catalytic ozonation over $\mathrm{Pt} / \mathrm{Al}_{2} \mathrm{O}_{3}$ and adsorption on catalyst at $\mathrm{pH} 3, \mathrm{pH} 5, \mathrm{pH} 7$ and $\mathrm{pH} 9$.

involving the adsorption of both pollutants and $\mathrm{O}_{3}$ over the catalyst, followed by surface oxidation without significant production of hydroxyl radicals [29].

The adsorption capacity of $\mathrm{Pt} / \mathrm{Al}_{2} \mathrm{O}_{3}$ for the organic compounds present in the synthetic solution was tested at different medium $\mathrm{pH}$ values that have been used throughout this study (Figure 5). The COD removal by adsorption was compared with the total COD abatement along time for noncatalytic and catalytic ozonation for the same $\mathrm{pH}$ values. As can be observed, for $\mathrm{pH}$ values 3 and 9, the COD eliminated by adsorption reached 5.2 and $4.9 \%$, respectively, whereas the greatest adsorption occurred at $\mathrm{pH} 7$ with $17.6 \%$ of COD decrease, followed by $\mathrm{pH} 5$ with $15.3 \%$. These results may be explained by the $p H_{z p c}$ of the catalyst (7.7) and the $p K_{a}$ of the phenolic acids (between 4.5 and 5.5). In fact, as mentioned before for liquid $\mathrm{pH}$ higher than 7.7 , both catalyst surface and phenolic acids are negatively charged, leading therefore to repulsive electrostatic interactions developing between the $\mathrm{Pt} / \mathrm{Al}_{2} \mathrm{O}_{3}$ surface and the phenolic acid anions, inhibiting as a consequence the adsorption process. Apparently, a surface positively charged ( $\mathrm{pH}$ 3) seems to be also unfavourable for the phenolic compound adsorption. It is also possible to observe that for non-catalytic ozonation, the best COD removal efficiency was obtained for $\mathrm{pH}$ values above and below the $p K_{a}$ value of the phenolic acids, whereas for catalytic ozonation, the COD abatement decreases above the $p H_{z p c}$ value of the catalyst. The main catalytic ozonation pathway for this catalyst is then believed to involve the pollutant oxidation in the liquid bulk by hydroxyl radicals produced by ozone decomposition at the catalyst surface. However, the adsorption tests showed that this catalyst also has some capacity to adsorb the phenolic acids present on the synthetic solution, indicating that some surface oxidation reactions may still occur.

\subsubsection{Catalyst stability}

Platinum (Pt) leaching was not considered due to its low amount in the catalyst. However, aluminium (Al) present

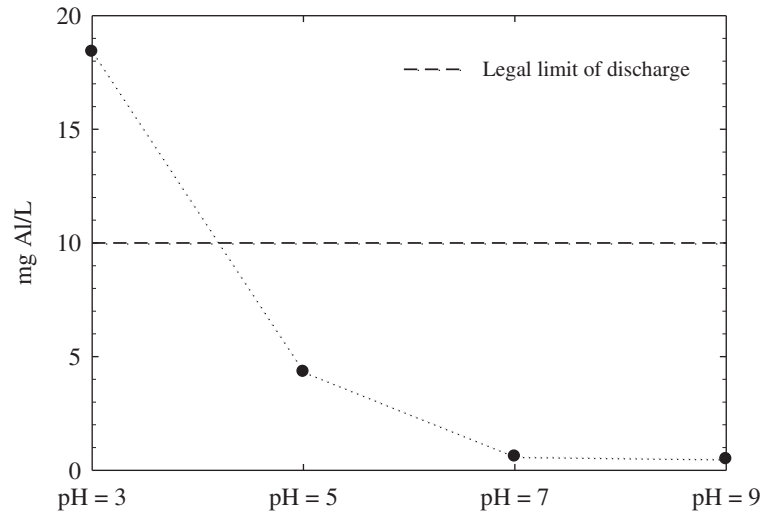

Figure 6. $\mathrm{Al}$ leached from the $\mathrm{Pt} / \mathrm{Al}_{2} \mathrm{O}_{3}$ catalyst after 120 minutes of catalytic ozonation at different $\mathrm{pH}$ values.

in the support can leach from the solid, as seen in Figure 6, reporting that after 120 minutes of oxidation the maximum elution was $18.4 \mathrm{mgAl} / 1$ for $\mathrm{pH} 3$ (which corresponds to barely $0.35 \%$ of the initial Al of the catalyst introduced in the reactor). A high dependence was then observed between $\mathrm{Al}$ leakage and $\mathrm{pH}$, decreasing down to $4.3,0.6$ and $0.5 \mathrm{mgAl} / 1$ for $\mathrm{pH}$ values 5, 7 and 9, respectively, which are already below the legal limits of discharge of $10 \mathrm{mgAl} / 1$ according to Portuguese environmental law.

Sequential feed-batch trials were also performed, aiming to gather a first idea about the catalyst activity for longer operation times. Systematic injections of fresh synthetic effluent were carried out, at each 120 minutes, to guarantee the same initial concentration for five consecutive tests. After every run, the catalyst was filtered and dried before the next use. In all cases the experimental conditions were the same and the $\mathrm{pH}$ value $(\mathrm{pH} 3)$ was controlled during all reaction time. Figures $7(\mathrm{a})$ and (b) represent $\mathrm{TPh}$ and COD removal, respectively. Even though $\mathrm{TPh}$ removal remains practically unchanged, a slight decrease in COD efficiency is found. After each 120 minutes batch, TPh elimination was always within the range of $79.4-86.6 \%$ and COD stabilized around $35-40 \%$ after the second run.

Figure 8 shows the quantity of aluminium leached along the reuses, which is not below the legal limits of discharge; still, the maximum Al concentration in the liquid corresponds to $0.35 \%$ of the initial $\mathrm{Al}$ in the catalyst. In the study performed by Martins and Quinta-Ferreira [29] using a similar phenolic wastewater, the Mn-Ce-O 70/30 catalyst revealed a higher leaching problem associated to $\mathrm{Mn}$; the applicability of a noble metal-supported catalyst seems to be less acquiescent to elution than the catalysts based on transition metals.

\subsubsection{Fresh and used catalyst characterization}

Through Figure 9, the morphology of $\mathrm{Pt} / \mathrm{Al}_{2} \mathrm{O}_{3}$ was assessed by SEM photographs for the fresh (a) and used (b) catalyst (for $\mathrm{pH} 3$ ). For the $\times 50,000$ magnification one 

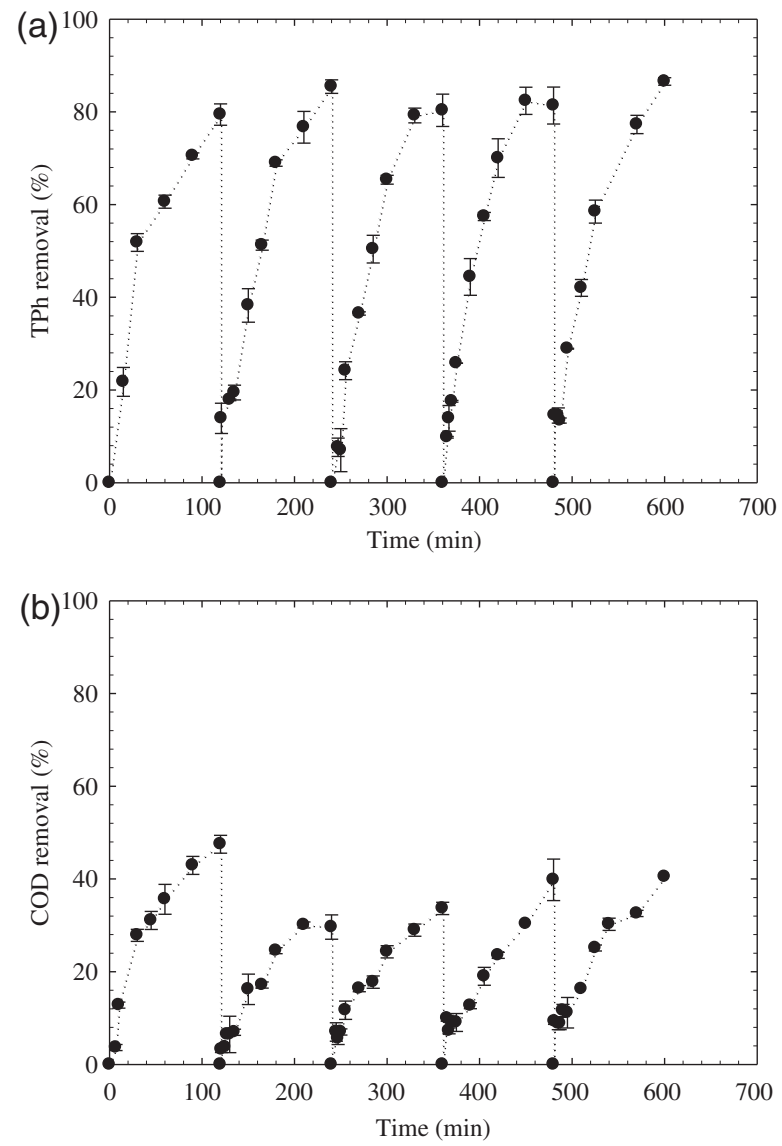

Figure 7. Effect of the catalyst reuse on TPh (a) and COD (b) degradation by catalytic ozonation over $\mathrm{Pt} / \mathrm{Al}_{2} \mathrm{O}_{3}(10 \mathrm{~g} / \mathrm{l}$ of catalyst, $0.02 \mathrm{gO}_{3} / 1$.min and $\mathrm{pH}=3$ ).

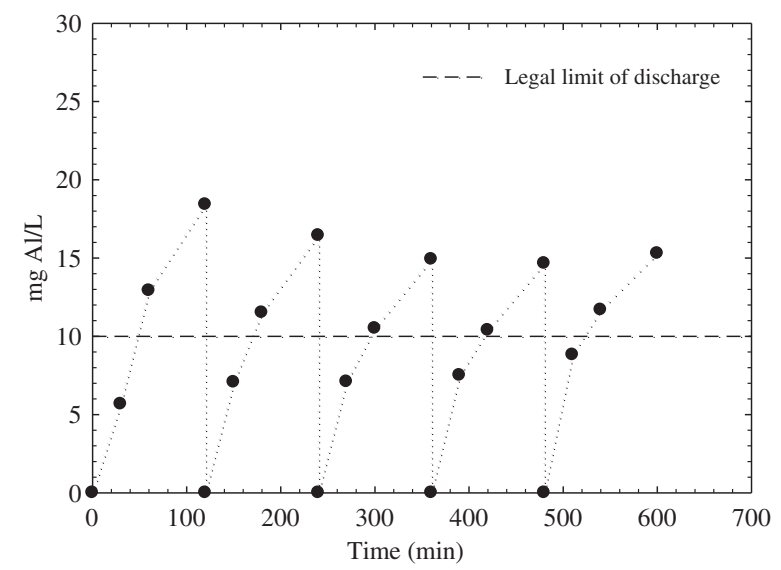

Figure 8. $\mathrm{Al}$ leached from $\mathrm{Pt} / \mathrm{Al}_{2} \mathrm{O}_{3}$ as a function of time for a sequential batch experiment with a phenolic mixture injection each 120 minutes $\left(10 \mathrm{~g} / 1\right.$ of catalyst, $0.02 \mathrm{gO}_{3} / 1$.min and $\left.\mathrm{pH} 3\right)$.

can observe the formation of filaments in the used catalyst, which can be caused by the fractionation of particles, resulting from mechanical agitation.

In the particle size distribution analysis, $d$ (50) represents the average equivalent diameter, which is defined (a)

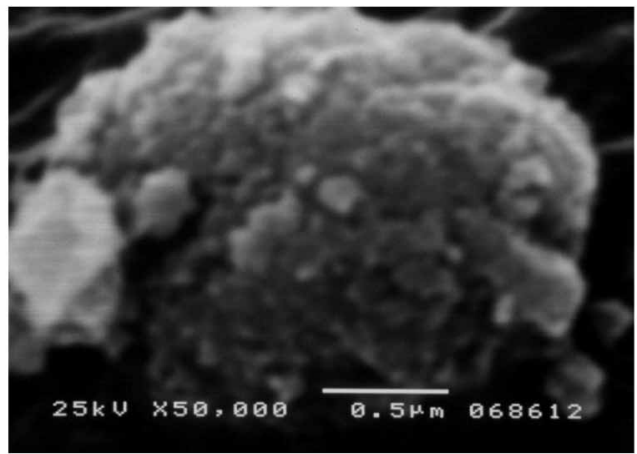

(b)

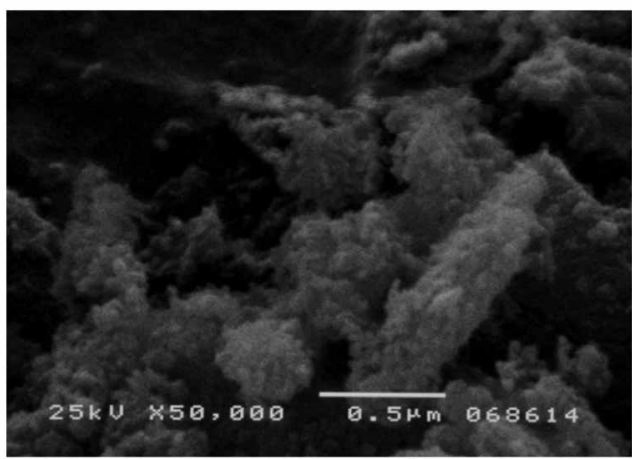

Figure 9. SEM photographs showing different scales/magnifications of fresh (a) and used (b) $\mathrm{Pt} / \mathrm{Al}_{2} \mathrm{O}_{3}$ catalyst.

as the diameter where 50 mass- $\%$ (of the particles) of the powder has a larger equivalent diameter, and the other 50 mass- $\%$ has a smaller equivalent diameter. Thus, the fresh catalyst has a diameter lower than $16 \mu \mathrm{m}$ while inferior values, less than $7 \mu \mathrm{m}$, are attained for the used sample, noting that the catalyst may have a low resistance to mechanical agitation.

Figure 10(a) represents XRD of the fresh and used catalyst ( $\mathrm{pH} 3$ ); no differences were detected in terms of the solid structure before and after catalytic ozonation of the synthetic effluent, since the two diffractograms are almost superimposed, so that only one was used to do the peak indexation (Figure 10(b)). The only compound that can justify the two peaks at the beginning is the hydration of alumina-forming gibbsite. Platinum was also indexed, but its low amount may not be detectable and the peaks can be also attributed to alumina. In order to index the remaining peaks, two types of alumina with different structures were used, one a simple cubic $\left(\gamma-\mathrm{Al}_{2} \mathrm{O}_{3}\right)$ and the other a face-centred cubic $\left(\chi-\mathrm{Al}_{2} \mathrm{O}_{3}\right)$.

The nitrogen adsorption isotherms, presented in Figure 11(a) for fresh and used $\mathrm{Pt} / \mathrm{Al}_{2} \mathrm{O}_{3}$ catalysts, show a type-IV isotherm with a hysteresis loop in the high range of relative pressure, suggesting a hysteresis type $\mathrm{H} 1$ in accordance with the International Union of Pure and Applied Chemistry (IUPAC) [41]. It is noted that for high relative pressures, in this case higher than 0.8 , capillary condensation takes place, giving an extraordinary 
Counts

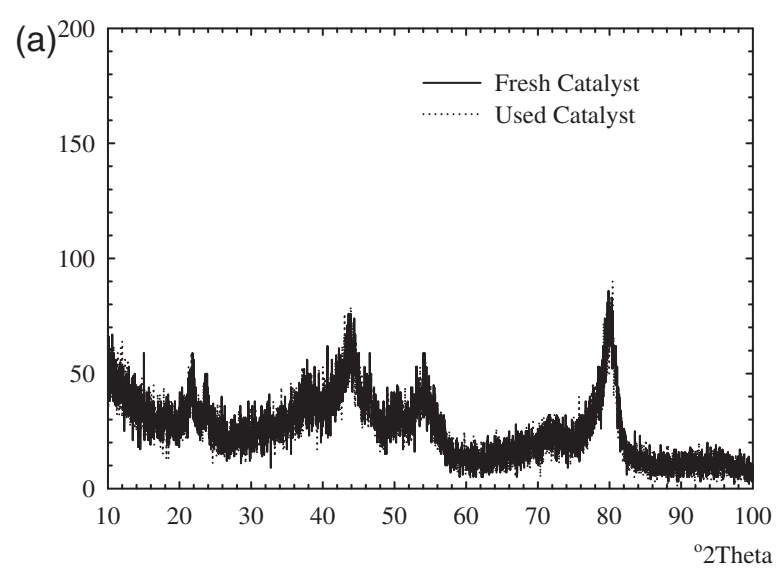

(b)

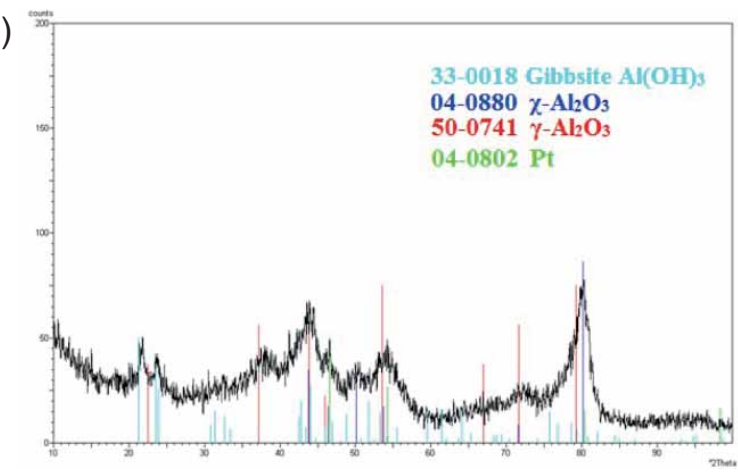

Figure 10. X-ray diffraction of fresh and used $\mathrm{Pt} / \mathrm{Al}_{2} \mathrm{O}_{3}$ catalyst (a) and peaks indexation of $\mathrm{Pt}, \gamma-\mathrm{Al}_{2} \mathrm{O}_{3}$ (50-0741), $\chi-\mathrm{Al}_{2} \mathrm{O}_{3}$ (04-0880) and gibbsite (b).

adsorption volume increase, corresponding to mesoporous $\left(2 \times 10^{-3}-0.05 \mu \mathrm{m}\right.$ pore diameter). The initial part of the type-IV isotherm is attributed to monolayer-multilayer adsorption. Moreover, from the pore size distribution analysis (Figure 11(b)), the average pore diameter attained by mercury porosimetry was 0.0331 and $0.0351 \mu \mathrm{m}$, for fresh and used catalysts, respectively, which is in agreement with the mesoporous range associated to the isotherm. The determined BET surface area $\left(S_{B E T}\right)$ for the used catalyst was 88 $\mathrm{m}^{2} / \mathrm{g}$, which is similar to that obtained for the fresh solid $\left(84 \mathrm{~m}^{2} / \mathrm{g}\right)$.

\subsection{Parent phenolic compound depletion and toxicity analysis}

The individual concentration of the six parent phenolic acids was monitored by HPLC. Figure 12 represents the removal profile for all compounds along non-catalytic (a) and catalytic (b) ozonation, for $\mathrm{pH} 3$. In the non-catalytic treatment the high efficiency of ozone in the total degradation of the phenolic compounds after 120 minutes of reaction is noticeable. 3,4-dimethoxybenzoic acid was the exception since, at the end of the experiment, $2.5 \%$ of the compound still remained in solution. 3,4,5-trihydroxybenzoic acid showed the highest reactivity, since total removal
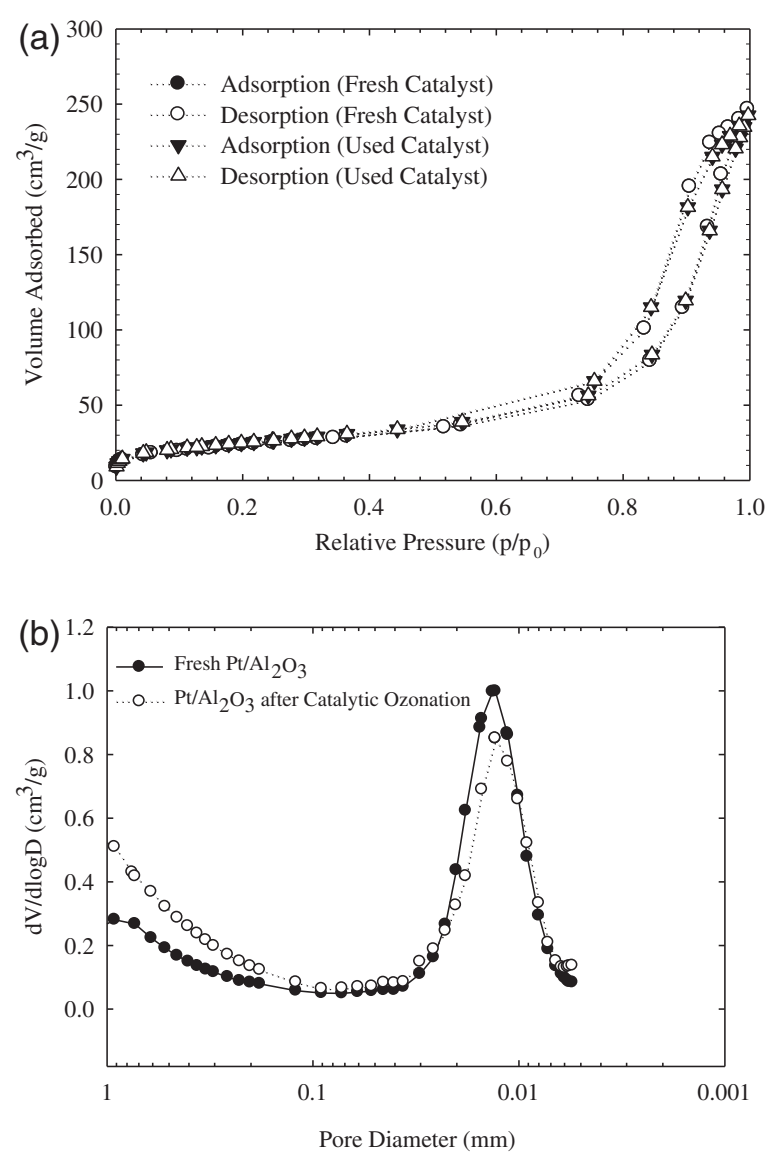

Figure 11. Fresh and used $\mathrm{Pt} / \mathrm{Al}_{2} \mathrm{O}_{3}$, BET isotherm (a) and pore size distribution (b) obtained with mercury porosimetry.

was achieved within 30 minutes of ozonation. After this experimental time, the following order of degradation rate was achieved for non-catalytic ozonation: 3,4,5trihydroxybenzoic acid $(3 \mathrm{OH})>3$,4-dihydroxybenzoic acid $(2 \mathrm{OH})>$ trans-cinnamic acid $(1$ external double bond) $\approx 3,4,5$-trimetoxybenzoic acid $\left(3 \mathrm{CH}_{3} \mathrm{O}\right) \approx 4$ hydroxybenzoic acid $(1 \mathrm{OH})>3$,4-dimethoxybenzoic acid $\left(2 \mathrm{CH}_{3} \mathrm{O}\right)$. The most susceptible compounds to ozonation are those containing $\mathrm{C}-\mathrm{C}$ double bonds outside the aromatic ring and specific functional groups (e.g. $\mathrm{OH}, \mathrm{CH}_{3}$, $\mathrm{CH}_{3} \mathrm{O}$ ) [23]. It is therefore possible to establish a relation between the number and type of aromatic ring substitute groups, the type of bonds and the reactivity of the acids once molecular ozone attacks preferentially through electrophilic pathways, which is enhanced by the presence of a high electronic density due to donating groups in the benzenic ring, such as methoxy $\left(\mathrm{CH}_{3} \mathrm{O}\right)$ and hydroxyl $(\mathrm{OH})$ [30]. Indeed, the 3,4,5-trihydroxybenzoic acid has three strong electron donating groups $(\mathrm{OH})$, which are highly reactive substitutes, followed by the 3,4-dihydroxybenzoic acid with two $\mathrm{OH}$ groups. The trans-cinnamic acid has an external double bond that is able to be broken and form intermediate compounds. The 3,4,5-trimetoxybenzoic acid has three moderate electron donating groups $\left(\mathrm{CH}_{3} \mathrm{O}\right)$, being then less 

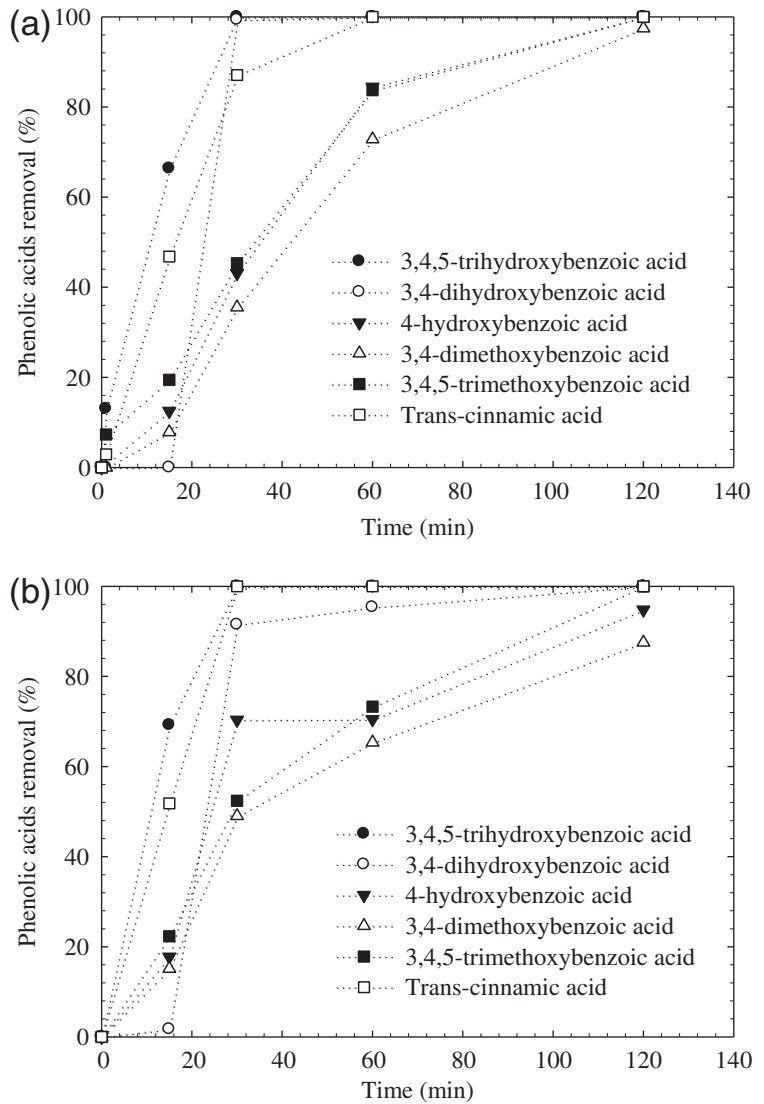

Figure 12. Parent phenolic acids (3,4,5-trihydroxybenzoic, 3,4-dihydroxybenzoic, 4-hydroxybenzoic, 3,4-dimethoxybenzoic, 3,4,5-trimethoxybenzoic and trans-cinnamic acids) removal profile by non-catalytic (a) and catalytic ozonation (b), for $\mathrm{pH} 3$.

reactive than the former acids, even with three substituent groups. The reactivity of the 4-hydroxybenzoic acid is slightly higher than that of the 3,4-dimethoxybenzoic acid due to the presence of one strong electron donating group $(\mathrm{OH})$ in the 4-hydroxybenzoic acid structure, while the 3,4-dimethoxybenzoic acid only possesses one moderate electron donating group $\left(\mathrm{CH}_{3} \mathrm{O}\right)$.

When the catalyst is added, it leads to a slightly higher degradation rate up to 30 minutes (Figure 12(b)). After this time, the phenolic acid removal slows down. Once more, the 3,4,5-trihydroxybenzoic acid was more reactive than the other acids, since total degradation of this compound occurred after 30 minutes of reaction. Then, the following order of reactivity can be established: 3,4,5-trihydroxybenzoic acid $>$ trans-cinnamic acid $>3,4-$ dihydroxybenzoic acid $>3,4,5$-trimetoxybenzoic acid $>4$ hydroxybenzoic acid $>3,4$-dimethoxybenzoic acid. There are two main differences between non-catalytic and catalytic ozonation reactivity order. The trans-cinnamic acid was more reactive than the 3,4-dihydroxybenzoic acid in the catalytic system. Moreover, in these reaction conditions, the 4-hydroxybenzoic acid besides the 3,4-dimethoxybenzoic acid was not completely degraded. The presence of the catalyst promotes the formation of hydroxyl radicals, which
Table 2. Values of $E C_{20}$ and $E C_{50}$ along the treatment time by non-catalytic and catalytic ozonation ( $\mathrm{pH} 3)$.

\begin{tabular}{cccccc}
\hline & \multicolumn{2}{c}{ Non-catalytic ozonation } & & \multicolumn{2}{c}{ Catalytic ozonation } \\
\cline { 2 - 3 } \cline { 6 - 6 } Time (min) & $E C_{20}(\%)$ & $E C_{50}(\%)$ & & $E C_{20}(\%)$ & $E C_{50}(\%)$ \\
\hline 0 & 10.0 & 35.5 & & 10.0 & 35.5 \\
30 & 15.0 & - & & 19.9 & 52.1 \\
60 & 13.9 & - & & 11.1 & 42.6 \\
120 & 22.4 & - & & 28.4 & - \\
\hline
\end{tabular}

are less selective species than ozone, reacting with a wider range of pollutants and not exclusively with molecules encompassing high electronic density sites. Thus, molecular $\mathrm{O}_{3}$ reacts more quickly with the phenolic compounds, while $\mathrm{HO}$ is also able to decompose saturated organic byproducts formed during the oxidation.

The phenolic compounds are well known by their phytotoxicity and, therefore, by their negative impact over our sensitive ecosystems. Within this context, applied treatment should be able to reduce the effluent toxicity to safeguard life when the wastewater is discharged into natural stream waters. Hence, the eco-toxicity of the synthetic effluent was checked through the effective concentrations of effluent $(E C)$, which provokes the light inhibition of $20 \%$ and $50 \%$ of the microorganisms' population $\left(E C_{20}\right.$ and $\left.E C_{50}\right)$ along the purification time by non-catalytic and catalytic ozonation at $\mathrm{pH} 3$, being the results shown in Table 2. For the non-catalytic system, $E C_{20}$ increased for the first 30 minutes of reaction from 10.0 to $15.0 \%$, having a slight reduction after 60 minutes to $13.9 \%$, probably due to the formation of more toxic intermediate compounds, whereas at the end $22.4 \%$ was reached. The $E C_{50}$ values could not be calculated, since even the undiluted wastewater was not able to inhibit $50 \%$ of the bacteria population. Nonetheless, the effluent may still be considered to have a significant ecological impact due to the low level of $E C_{20}$. In the catalytic ozonation, the eco-toxicity removal for $E C_{20}$ (after 120 minutes) was $28.4 \%$ and after 60 minutes a large character reduction occurs with the $E C_{50}$ value out of the scope of the instrument, which means that even the undiluted treated solution cannot provoke the inhibition of $50 \%$ of the bacteria activity.

\section{Conclusions}

In non-catalytic and catalytic ozonation over the $\mathrm{Pt} / \mathrm{Al}_{2} \mathrm{O}_{3}$ catalyst, it was verified that the medium $\mathrm{pH}$ affected the rate of ozone decomposition and the formation of hydroxyl radicals. The heterogeneous system for $\mathrm{pH} 7$ was found to be an interesting solution, with 93.0 and $47.7 \%$ of TPh and COD removal, respectively, after 120 minutes. For $\mathrm{pH} 3$, catalytic ozonation was affected by the presence of radical scavengers, meaning that the reaction pathway was mainly developed through hydroxyl radicals produced by the decomposition of ozone over the catalyst surface. No 
significant structural differences were observed between the fresh and used solid. After 120 minutes of reaction, the recovered catalyst showed negligible aluminium leaching behaviour. Moreover, during a sequence of feed-batch trials involving the catalyst reutilization, almost constant activity during the operation time was observed. According to eco-toxicological tests, the effluent ecological impact was reduced after the ozonation treatment.

\section{Acknowledgements}

The authors would like to acknowledge the Fundação para a Ciência e Tecnologia, Portugal, for financial support under the contract PTDC/EQU-ERQ/113308/2009. Rui C. Martins gratefully acknowledges the Fundação para a Ciência e Tecnologia, for financial support under the Post-Doc grant (SFRH/BPD/72200/2010).

\section{References}

[1] M. Pera-Titus, V. García-Molina, M.A. Baños, J. Giménez, and S. Esplugas, Degradation of chlorophenols by means of advanced oxidation processes: A general review, Appl. Catal. B 47 (2004), pp. 219-256.

[2] V.J. Inglezakis and S.G. Poulopoulos, Adsorption, Ion Exchange and Catalysis - Design of Operations and Environmental Applications, Elsevier B V, Amsterdam, 2006.

[3] R. Schwarzenbach, T. Egli, T.B. Hofstetter, U. Gunten, and B. Wehrli, Global water pollution and human health, Annu. Rev. Environ. Resour. 35 (2010), pp. 109-136.

[4] D. Mantzavinos and N. Kalogerakis, Treatment of olive mill effluents Part I. Organic matter degradation by chemical and biological processes - an overview, Environ. Int. 31 (2005), pp. 289-295.

[5] I.E. Kapellakis, K.P. Tsagarakis, and J.C. Crowther, Olive oil history, production and by-product management, Rev. Environ. Sci. Biotechnol. 7 (2008), pp. 1-26.

[6] F.A. El-Gohary, M.I. Badawy, M.A. El-Khateeb, and A.S. El-Kalliny, Integrated treatment of olive mill wastewater $(O M W)$ by the combination of Fenton's reaction and anaerobic treatment, J. Hazard. Mater. 162 (2009), pp. 1536-1541.

[7] B.K. Mert, T.Y. Yonar, M.Y. Kiliç, and K. Kestioğlu, Pretreatment studies on olive oil mill effluent using physicochemical, Fenton and Fenton-like oxidations processes, J. Hazard. Mater. 174 (2010), pp. 122-128.

[8] J. Beltran-Heredia, J. Torregrosa, J. Dominguez, and J. Peres, Kinetics of the reaction between ozone and phenolic acids present in agro-industrial wastewaters, Water Res. 35 (2001), pp. 1077-1085.

[9] R.F. Nogueira, A.G. Trovó, and D.F. Modé, Solar photodegradation of dichloroacetic acid and 2,4-dichlorophenol using an enhanced photo-Fenton process, Chemosphere 48 (2002), pp. 385-391.

[10] J.B. Peñarroya, Coupled photochemical-biological system to treat biorecalcitrant wastewaters, Ph.D. diss., Universitat de Barcelona, 2007.

[11] R. Martins, A. Silva, S. Castro-Silva, P. Garção-Nunes, and R. Quinta-Ferreira, Adopting strategies to improve the efficiency of ozonation in the real-scale treatment of olive oil mil wastewaters, Environ. Technol. 31 (2010), pp. 1459-1469.

[12] H. Valdés, R. Tardón, and C. Zaror, Methylene blue removal from contaminated waters using heterogeneous catalytic ozonation promoted by natural zeolite: Mechanism and kinetic approach, Environ. Technol. (in press), doi: 10.1080/ 09593330.2011 .650222
[13] D. Li and J. Qu, The progress of catalytic technologies in water purification: A review, J. Environ. Sci. 21 (2009), pp. 713-719.

[14] L.F. Liotta, M. Gruttadauria, G.D. Carlo, G. Perrini, and V. Librando, Heterogeneous catalytic degradation of phenolic substrates: Catalysts activity, J. Hazard. Mater. 162 (2009), pp. 588-606.

[15] C.A.G. Perez, Application of heterogeneous catalysts in ozonation of model compounds in water, M.Sc. thesis, University of Saskatchewan, 2010.

[16] R.C. Martins and R.M. Quinta-Ferreira, Phenolic wastewaters depuration and biodegradability enhancement by ozone over active catalysts, Desalination 270 (2011), pp. 90-97.

[17] M. Carbajo, F. Rivas, F. Beltrán, P. Alvarez, and F. Medina, Effects of different catalysts on the ozonation of pyruvic acid in water, Ozone Sci. Eng. 28 (2006), pp. 229-235.

[18] N. Karpel Vel Leitner and H. Fu, pH effects on catalytic ozonation of carboxylic acids with metal on metal oxides catalysts, Top. Catal. 33 (2005), pp. 249-256.

[19] B. Kaspryzk-Hordern, M. Ziólek, and J. Nawrocki, Catalytic ozonation and methods of enhancing molecular ozone reactions in water treatment, Appl. Catal. B 46 (2003), pp. 639-669.

[20] K. Pirkanniemi and M. Sillanpää, Heterogeneous water phase catalysis as an environmental application: A review, Chemosphere 48 (2002), pp. 1047-1060.

[21] C.C. Chang, C.Y. Chiu, C.Y. Chang, C.F. Chang, Y.H. Chen, D.R. Ji, J.Y. Tseng, and Y.H. Yu, Pt-catalysed ozonation of aqueous phenol solution using high-gravity rotating packed bed, J. Hazard. Mater. 168 (2009), pp. 649-655.

[22] J. Lin, T. Nakajima, T. Jomoto, and K. Hiraiwa, Effective catalysts for wet oxidation of formic acid by oxygen and ozone, Ozone Sci. Eng. 22 (2000), pp. 241-247.

[23] C.C. Chang, C.Y. Chiu, C.Y. Chang, C.F. Chang, Y.H. Chen, D.R. Ji, Y.H. Yu, and P. Chiang, Combined photolysis and catalytic ozonation of dimethyl phthalate in a highgravity rotating packed bed, J. Hazard. Mater. 161 (2009), pp. 287-293.

[24] B. Legube and N. Karpel Vel Leitner, Catalytic ozonation: A promising advanced oxidation technology for water treatment, Catal. Today 53 (1999), pp. 61-72.

[25] D.S. Pines and D.A. Reckhow, Solid phase catalytic ozonation process for the destruction of a model pollutant, Ozone Sci. Eng. 25 (2003), pp. 25-39.

[26] Y. Zhou, W. Zhu, and X. Chen, Catalytic activity of ceriumdoped $\mathrm{Ru} / \mathrm{Al}_{2} \mathrm{O}_{3}$ during ozonation of dimethyl phthalate, Front. Environ. Sci. Eng. China 2 (2008), pp. 354-357.

[27] V. Balice and O. Cera, Acidic phenolic fraction of the olive vegetation water determined by a gas chromatographic method, Grasas Aceites 35 (1984), pp. 178-180.

[28] J. Rivera-Utrilla, I. Bautista-Toledo, M.A. Ferro-García, and C. Moreno-Castilla, Activated carbon surface modifications by adsorption of bacteria and their effect on aqueous lead adsorption, J. Chem. Technol. Biotechnol. 76 (2001), pp. 1209-1215.

[29] R.C. Martins and R.M. Quinta-Ferreira, Catalytic ozonation of phenolic acids over a Mn-Ce-O catalyst, Appl. Catal. B 90 (2009), pp. 268-277.

[30] R.C. Martins, H.C. Leal, and R.M. Quinta-Ferreira, Single and catalytic ozonation for phenolic wastewaters remediation, in Current Themes in Engineering Technology, S.-I. Ao, M.A. Amouzegar, and S.-S. Chen, eds., American Institute of Physics, New York, 2008, pp. 46-56.

[31] A. Greenberg, L. Clesceri, and A. Eaton, Standard Methods for the Examination of Water and Wastewater, American Public Health Association, Washington, DC, 1985. 
[32] S. Esplugas, S. Contreras, and D. Ollis, Engineering aspects of the integration of chemical and biological oxidation: Simple mechanistic models for the oxidation treatment, J. Environ. Eng. 130 (2004), pp. 967-974.

[33] V. Sarria, S. Parra, N. Adler, P. Péringer, N. Benitez, and C. Pulgarin, Recent developments in the coupling of photoassisted and aerobic biological processes for the treatment of biorecalcitrant compounds. Catal. Today 6 (2002), pp. 301-315.

[34] R. Martins, N. Amaral-Silva, and R. Quinta-Ferreira, Ceria based solid catalysts for Fenton's depuration of phenolic wastewaters, biodegradability enhancement and toxicity removal, Appl. Catal. B 99 (2010), pp. 135-144.

[35] J. Beltran, J. Torregrosa, J.R. Dominguez, and J.A. Peres, Ozonation kinetics of phenolic compounds present in table olive wastewaters: p-hydroxybenzoic acid, tyrosol and pcoumaric acid, Chem. Eng. Comm. 184 (2001), pp. 157-174.
[36] Y. Lin, Z. Peng, and X. Zhang, Ozonation of estrone, estradiol, diethylstilbestrol in waters, Desalination 249 (2009), pp. 235-240.

[37] F.J. Beltrán, J.F. García-Araya, and I. Giráldez, Gallic acid water ozonation using activated carbon, Appl. Catal. B 63 (2006), pp. 249-259.

[38] A. Alvares, C. Diaper, and S. Parsons, Partial oxidation by ozone to remove recalcitrance from wastewaters - a review, Environ. Technol. 22 (2001), pp. 409-427

[39] V.S.R.R. Pullabhotla, C. Southway, and S.B. Jonnalagadda, Ozone initiated oxidation of hexadecane with metal loaded $\gamma-\mathrm{Al}_{2} \mathrm{O}_{3}$ catalysts, Catal. Lett. 124 (2008), pp. 118-126.

[40] J. Ma, M. Sui, T. Zhang, and C. Guan, Effect of $p H$ on $\mathrm{MnOx} / \mathrm{GAC}$ catalysed ozonation for degradation of nitronbenzene, Water Res. 39 (2005), pp. 779-786.

[41] J. Figueiredo and F. Ribeiro, Catálise Heterogénea, Fundação Calouste Gulbenkian, Lisboa, 2007. 